\title{
Economic Growth, Poverty, Urbanization, and the Small and Medium Enterprises (SMEs) in Indonesia: Analysis of Cointegration and Causality
}

\author{
Hadi Jauhari $^{1 *}$; Periansya $^{2}$ \\ ${ }^{1}$ Department of Business Administration, Politeknik Negeri Sriwijaya \\ Jln. Srijaya Negara, Sumatera Selatan 30139, Indonesia \\ ${ }^{2}$ Department of Accounting, Politeknik Negeri Sriwijaya \\ Jln. Srijaya Negara, Sumatera Selatan 30139, Indonesia \\ 'ha.di@polsri.ac.id; ${ }^{2}$ periansya@polsri.ac.id
}

Received: $15^{\text {th }}$ July 2020/ Revised: $31^{\text {st }}$ August 2020/ Accepted: $9^{\text {th }}$ November 2020

\begin{abstract}
How to Cite: Jauhari, H., \& Periansya. (2021). Economic Growth, Poverty, Urbanization, and the Small and Medium Enterprises (SMEs) in Indonesia: Analysis of Cointegration and Causality. Binus Business Review, 12(2), $143-150$. https://doi.org/10.21512/bbr.v12i2.6573
\end{abstract}

\begin{abstract}
In Indonesia, poverty is still considered a serious problem, even though the number of poor people continues to decline significantly. The research aimed to investigate whether there was cointegration between the role of Small and Medium Enterprises (SMEs), economic growth, and poverty alleviation or not in Indonesia. Secondary data were compiled from annual data in 2000-2019. Data analysis applied the cointegration test and Vector Error Correction Model (VECM) test. The results show a one-way causality between poverty and economic growth, urbanization and economic growth, the role of SMEs and economic growth, and the role of SMEs and poverty. In addition, the results of the VECM analysis suggest that the role of SMEs has a positive effect on poverty in the first year. It means that it takes a year to find out the impact of the increasing role of SMEs on poverty at the later stage. The research has several implications for government, namely: (i) compiling work programs that touch the community directly and strengthen the development of local wisdom products, (ii) conducting more intense training, (iii) emphasizing on improving the quality and standards of local wisdom products, and (iv) building rural infrastructure that can facilitate the economic processes in the village.
\end{abstract}

Keywords: economic growth, poverty, urbanization, Small and Medium Enterprises (SMEs), cointegration, causality

\section{INTRODUCTION}

In Indonesia, poverty is still considered a serious problem, although the number of poor people continues to decline significantly. Poverty is a condition of inability to meet basic needs as measured by the level of expenditure. Residents with an average per capita expenditure per month below the poverty line are categorized as poor people (Badan Pusat Statistik, 2019).

Based on data from Badan Pusat Statistik (2019), especially the data from 2006 to September 2019, poverty levels in Indonesia decreased. The number of poor people continued to decline from $11,22 \%$ in
March 2015 to 9,41\% in March 2019. Then, it reached 24,79 million people or $9,22 \%$ of the population in September 2019. This figure was $0,19 \%$ lower compared to March 2019. The number of poor people in the last seven years has shown a declining trend. The Indonesian economy, since 2013, has undergone at least four phases of change, namely the expansion phase in 2013-2014, the downward phase in 2015, the consolidation phase in 2016, and the recovery phase in 2017 (BTN Properti, 2017). However, poverty is not merely a problem of lack of income and assets. It also concerns the problem of shortages, as the case in many urban or rural areas.

Furthermore, since the entry into force of the 
ASEAN Economic Community in early 2016, it has required Small and Medium Enterprises (SMEs) to compete with entrepreneurs from other ASEAN countries. SMEs are defined in Undang-Undang Number 20 of 2008. Small businesses can be individuals or business entities that are not subsidiaries or branches, either directly or indirectly from medium or large businesses. Medium business is a productive economic business carried out by individuals or business entities that are not subsidiaries or branches of the company, directly or indirectly, with the number of net assets or annual sales as stipulated in the law. SMEs play an essential role in encouraging the economic growth of developing countries (Manzoor, Wei, Nurunnabi, \& Abdul Subhan, 2019). They have become the backbone of the economies of Indonesia and ASEAN. Around 88,8-99,9\% of businesses formed in ASEAN countries are SMEs with employment reaching 51,7-97,2\%.

According to Tambunan (2019), business in Indonesia is dominated by SMEs. They contribute almost $100 \%$ of all existing companies but only contribute between $58 \%$ to $61 \%$ of gross domestic product. Therefore, cooperation for the development and resilience of SMEs needs to be prioritized. The same thing is revealed by Laily and Kurniawan (2016) that the emergence of small and medium enterprises can improve the country's economy. In contrast, there is an argument that micro and small business actors in Indonesia do not affect economic growth. It is because SMEs do not pay taxes on business activities, so they do not contribute to increasing economic growth (Yanah, 2019).

From various causes of poverty, the role of SMEs and economic growth can help to alleviate poverty. It is important to conduct the research, considering poverty is an urgent national problem and requires systematic and comprehensive management measures and approaches to reduce inequality and create a dignified life. Increasing economic growth in the short term contributes to poverty (Siani, 2020), and long-term contributes to poverty reduction (Garza-Rodriguez, 2018). Although the relationship between economic growth and poverty has been widely studied before, most empirical studies generally focus on correlation studies that assume that the only direction of causality is from growth to poverty (Khemili \& Belloumi, 2018). Those ensure that not all locations and sectoral growth components can contribute to poverty reduction. For this reason, the research connects urbanization with economic growth and poverty.

The researchers conduct a causality analysis between the role of SMEs, economic growth, and poverty alleviation in Indonesia by adding urbanization as a predetermined variable. It may reduce the level of poverty. The eradication causes faster poverty with higher economic growth and urbanization patterns (Datt, Ravallion \& Murgai, 2016). It is also explained that economic opportunities strongly influence migration flows. It means that economic development drives urbanization and not vice versa (Potts, 2016).
The level of urbanization in Indonesia is very fast due to the process of capitalization, reclassification, and migration. According to data from the National Development Planning Agency (BAPPENAS), in five years (2015-2020), the rate of urbanization is predicted to increase from $53,3 \%$ to $56,7 \%$ and projected to $66,6 \%$ in 2035 . This rate of urbanization is the highest in Asia (Hayyu, 2019). Urbanization results from an imbalance between economic growth in villages and cities (Wilonoyudho, Rijanta, Keban, \& Setiawan, 2017). It is also revealed that urbanization has an important role in reducing poverty, especially in rural areas in developing countries with similar economic and geographical conditions with Vietnam, such as the Philippines, Indonesia, Laos, and Cambodia (Arouri, Youssef, \& Nguyen, 2017). Urbanization affects not only the income and expenditure of rural households but also the inequality of income and urban-rural consumption.

Most recent studies on poverty are crosssectional studies, and few studies apply data with timeseries techniques. Many studies on economic growth, poverty, and the role of SMEs have been done, but the results have not been consistent. Table 1 shows summary of the previous research results.

The research intends to provide an understanding of the diversity of the effects of economic growth on poverty and the role of policies applied by the government. It is expected to test and learn whether there is cointegration between the roles of SMEs, economic growth, and poverty alleviation in Indonesia. Then, it also analyzes whether there is causality between economic growth and poverty alleviation and the role of SMEs in Indonesia. The findings of the research will have implications for the government of Indonesia as an evaluation material in the formulation of policies, especially institutions related to economic planning and development.

\section{METHODS}

The research applies a quantitative approach. The data are secondary, namely time series data from 2000-2019. They are obtained from several sources, such as the Indonesian Economic and Financial Statistics, Statistics Indonesia (Badan Pusat Statistik (BPS)), and Bank Indonesia (BI). Table 2 shows the definition and measurement of the used variables in the research.

In the research, SMEs and economic growth are endogenous variables. Meanwhile, urbanization is exogenous variable. The equation model is used as follows:

$$
\begin{aligned}
\operatorname{LnSME}_{\mathrm{st}} & =\beta_{01}+\beta_{11} \operatorname{LnPO}_{\mathrm{t}}+\gamma_{11} \operatorname{LnU}_{\mathrm{t}}+\varepsilon_{2 \mathrm{t}} \\
\mathrm{LnGDP}_{\mathrm{t}}= & \beta_{02}+\beta_{12} \operatorname{LnSME}_{\mathrm{st}}+\beta 22 \mathrm{LnPO}_{\mathrm{t}} \\
& +\gamma_{12} \operatorname{LnU}_{\mathrm{t}}+\varepsilon_{1 \mathrm{t}}
\end{aligned}
$$


Table 1 The Summary of Previous Research

\begin{tabular}{|c|c|c|}
\hline Researcher / Year & Method & Conclusions \\
\hline Siani (2020) & $\begin{array}{l}\text { A panel of Dynamic Ordinary Least Squares } \\
\text { (DOLS) and Fully Modified Ordinary Least } \\
\text { Squares (FMOLS) }\end{array}$ & $\begin{array}{l}\text { There is a two-way causal relationship between } \\
\text { economic growth and poverty in both the short and } \\
\text { long terms. }\end{array}$ \\
\hline Manzoor et al. (2019) & Fixed Effect Model (FEM) & $\begin{array}{l}\text { In the South Asian Association of Regional } \\
\text { Cooperation (SAARC) region, one of the main } \\
\text { factors in reducing poverty is the growth of SMEs. }\end{array}$ \\
\hline $\begin{array}{l}\text { Zafar, Waqas, and Nawaz } \\
\text { (2018) }\end{array}$ & Regression analysis & $\begin{array}{l}\text { The role of small and medium businesses has a } \\
\text { significant negative relationship with poverty. }\end{array}$ \\
\hline Garza-Rodriguez (2018) & Gregory-Hansen cointegration test & $\begin{array}{l}\text { There is a bidirectional causality relationship } \\
\text { between poverty reduction and economic growth. }\end{array}$ \\
\hline $\begin{array}{l}\text { Dewi, Majid, Aliasuddin, and } \\
\text { Kassim (2018) }\end{array}$ & $\begin{array}{l}\text { Autoregressive Distributed Lag (ARDL) } \\
\text { cointegration }\end{array}$ & $\begin{array}{l}\text { The poverty level can be reduced through long term } \\
\text { economic growth }\end{array}$ \\
\hline $\begin{array}{l}\text { Kowo, Adenuga, and Sabitu } \\
\text { (2019) }\end{array}$ & Regression analysis & $\begin{array}{l}\text { The role of SMEs development affects poverty } \\
\text { alleviation. }\end{array}$ \\
\hline Yalo and Nafiu (2016) & Regression analysis & $\begin{array}{l}\text { There is a positive relationship between Micro, } \\
\text { Small, and Medium Enterprises (MSMEs) and } \\
\text { poverty alleviation. }\end{array}$ \\
\hline $\begin{array}{l}\text { Edom, Inah, and Emori } \\
\text { (2015) }\end{array}$ & Ordinary Least Square (OLS) & $\begin{array}{l}\text { There is a positive relationship between poverty } \\
\text { alleviation and MSMEs. }\end{array}$ \\
\hline Nindi and Odhiambo (2015) & $\begin{array}{l}\text { Johansen Cointegration and Error Correction } \\
\text { Mechanism (ECM) }\end{array}$ & $\begin{array}{l}\text { Granger's economic growth does not lead to poverty } \\
\text { alleviation in Swaziland either in the short or long } \\
\text { term. Conversely, there is a causal relationship } \\
\text { between poverty alleviation to economic growth in } \\
\text { the short run. }\end{array}$ \\
\hline Khemili and Belloumi (2018) & ARDL test & $\begin{array}{l}\text { There is a unidirectional causal relationship between } \\
\text { economic growth to poverty. }\end{array}$ \\
\hline
\end{tabular}

(Source: Various Sources)

Table 2 Operational Definition of Variables

\begin{tabular}{lll}
\hline Variable & Definition & Measurement \\
\hline Economic Growth & $\begin{array}{l}\text { The continuing increase in the volume of production in } \\
\text { one country (Ivić, 2015). }\end{array}$ & $\begin{array}{l}\text { Gross Domestic Product (GDP) at constant prices } \\
\text { Poverty }\end{array}$ \\
& $\begin{array}{l}\text { Economic inability to meet basic food needs (Badan } \\
\text { Pusat Statistik, 2019) }\end{array}$ & $\begin{array}{l}\text { The percentage of the population below the poverty } \\
\text { line }\end{array}$ \\
Urbanization & $\begin{array}{l}\text { The level of urbanization of an area in terms of } \\
\text { proportion of the urban population against the entire } \\
\text { population (Badan Pusat Statistik, 2019). }\end{array}$ & The number of people who urbanize per year \\
& $\begin{array}{l}\text { Productive economic enterprises with assets of IDR } \\
\text { S0 million-500 million (small businesses) or 500 } \\
\text { million-10 billion (medium enterprises) (Sekretariat }\end{array}$ & The number of SMEs. \\
& Negara RI, 2008). & \\
\hline
\end{tabular}

(Source: Various Sources) 
$\mathrm{Ln}$ is the natural logarithm, and SMEs are the number of small and medium enterprises. Then, PO shows the percentage of the population below the poverty line while GDP is the gross domestic product at constant prices. Next, $U$ is the number of people who urbanize per year, and $t$ shows the period.

The research analyzes the time-series data with the vector autoregression model. It includes cointegration tests and VECM. The research also applies the Granger causality test to see the causal relationship between variables.

\section{RESULTS AND DISCUSSIONS}

Before cointegration testing is carried out, the data must be analyzed using stationarity test with unit root or Augmented Dickey-Fuller (ADF) test. Table 3 presents the results of stationary testing. From four stationarity tests on these variables, one variable (role of SMEs) has stationary at the first level. Meanwhile, these four variables are all stationary at the first difference. Table 3 shows that the optimal lag length of $\mathrm{p}^{*}=2$ is chosen. Cointegration tests are used to examine the long-run and short-run relationships between all variables.

A Vector Autoregressive (VAR) condition stability check is performed to test the stability of VAR estimation that is determined in the form of roots of polynomial characteristic. A VAR model is said to be stable if all of its roots have less modulus than 1 . From
Table 4, it appears that there is no root characteristic and modulus value that is more than 1 .

Next, the cointegration test is conducted by using the Johansen cointegration test with optimal lag $=1$. The result is presented in Table 5. It shows that there is one equation with a cointegration equation. Hence, the Vector Error Cointegration Model (VECM) is used. VECM estimation is to see the long and shortterm analysis.

Based on the causality test using the Granger causality in Table 6, the research obtains five results. First, there is a one-way causality between poverty on economic growth. It shows that if there is a change in the level of poverty, the level of economic growth also changes. However, conversely, economic growth does not have an impact on poverty. The results do not support the research conducted by Siani (2020), Dewi et al. (2018), and Garza-Rodriguez (2018). They found a bidirectional causal relationship between economic growth and poverty. Nevertheless, the results are in line with Nindi and Odhiambo (2015). They agreed that economic growth did not cause poverty alleviation.

The results also show that poverty is difficult to disappear if it does not rely on economic growth, so the government should start at the central and regional levels to reduce poverty with coordination, support, and cooperation of all parties through the provision of food, health services, education, and expansion employment opportunity. To overcome the problem of poverty, the government should create a work program that focuses

Table 3 The Result of Stationary Test

\begin{tabular}{llll}
\hline Variables & ADF test at level & First difference & Information \\
\hline Ln_GDP & $-1,9206(0,316)$ & $-4,5005(0,0027)^{*}$ & First Difference Stationary \\
Ln_PO & $-0,1247(0,958)$ & $-4,1060(0,0060)^{*}$ & First Difference Stationary \\
Ln_SMEs & $-3,2734(0,032) *$ & $-4,2663(0,0040)^{*}$ & First Difference Stationary \\
Ln_U & $-1,5259(0,498)$ & $-6,6983(0,0000)^{*}$ & First Difference Stationary \\
\hline
\end{tabular}

Note: $*$ shows the level of significance and critical value of $1 \%, 5 \%$, and $10 \%$

(Source: Processed Data)

Table 4 The Stability Test Results

\begin{tabular}{ll}
\hline Root & Modulus \\
\hline 0,975796 & 0,975796 \\
$0,517502-0,381666 \mathrm{i}$ & 0,543022 \\
$0,517502+0,381666 \mathrm{i}$ & 0,543022 \\
$-0,073473-0,597543 \mathrm{i}$ & 0,602043 \\
$-0,073473+0,597543 \mathrm{i}$ & 0,602043 \\
$-0,492321$ & 0,492321 \\
$0,145153-0,125822 \mathrm{i}$ & 0,192095 \\
$0,145153+0,125822 \mathrm{i}$ & 0,192095 \\
\hline
\end{tabular}

(Source: Processed Data) 
on the main problem of poverty, such as increasing the social protection budget, facilitating access to capital, providing training and business service skills, creating an infrastructure development center, and having connectivity that connects the economic center and supporting areas while strengthening the development of local wisdom products.

Second, urbanization and economic growth have a one-way causality relationship. It means that the movement of urbanization will encourage variation in economic growth in Indonesia. The results indicate that urbanization can be a driving force for economic growth in Indonesia if the population entering cities is individuals with certain skills and expertise, good education levels, and other supporting qualities. The results also contribute to policymakers that urbanization reduces disparities between regions. Therefore, it is necessary to manage urbanization appropriately. Development of basic infrastructure and facilities, such as health, education, markets, and rural roads, is expected to open new jobs. Then, it will also reduce unemployment rates and ultimately encourage equity and economic growth in Indonesia.
Third, there is a one-way causality between the role of SMEs and economic growth. It indicates that the role of SMEs will encourage economic growth in Indonesia. However, the economic growth does not contribute to the increase or decrease in the role of SMEs in Indonesia. The results support the findings of Manzoor et al. (2019) and Laily and Kurniawan (2016) that SMEs play an essential role in encouraging the economic growth. However, the research results are different from Yanah (2019). The results suggest an increase in the optimal role of SMEs as a booster of economic growth and employment in Indonesia. These findings have some implications for the role of SMEs. For this reason, the government should continue to conduct more intense training and put emphasis on improving product quality and standards to produce highly competitive products.

Fourth, there is no two-way causality between urbanization and poverty. It implies that changes in urbanization will not cause changes in poverty and vice versa. Poverty also does not contribute to the increase or decrease in the level of urbanization in Indonesia. The results do not support Arouri et al. (2017) that

Table 5 The Cointegration Test

\begin{tabular}{lcc}
\hline Hypothesized No. of Cointegrating Equation (CE(s)) & $\mathbf{5 \%}$ of Critical Value & Prob.** \\
\hline None* & 47,85613 & 0,0029 \\
At most 1 & 29,79707 & 0,0569 \\
At most 2 & 15,49471 & 0,2097 \\
At most $3 *$ & 3,841466 & 0,0250 \\
\hline Hypothesized No. of Cointegrating Equation (CE(s)) & $\mathbf{5 \%}$ of Critical Value & Prob. \\
\hline None* & 27,58434 & 0,0238 \\
At most 1 & 21,13162 & 0,1198 \\
At most 2 & 14,26460 & 0,6124 \\
At most $3 *$ & 3,841466 & 0,0250 \\
\hline
\end{tabular}

Note: Max-eigenvalue test indicates 1 cointegrating eqn(s) at the 0,05 level, and $*$ denotes rejection of the hypothesis at the 0,05 level

(Source: Processed Data)

Table 6 The Results of Granger Causality Test

\begin{tabular}{lccc}
\hline Null Hypothesis & Observation & F-Statistic & Prob. \\
\hline LN_PO does not Granger cause LN_GDP & 18 & 6,9284 & 0,0089 \\
LN_GDP does not Granger cause LN_PO & & 0,57072 & 0,5787 \\
LN_U does not Granger cause LN_GDP & 18 & 3,65555 & 0,055 \\
LN_GDP does not Granger cause LN_U & & 0,66539 & 0,5307 \\
LN_SMEs does not Granger cause LN_GDP & 18 & 5,99647 & 0,0143 \\
LN_GDP does not Granger cause LN_SMEs & & 0,07928 & 0,9242 \\
LN_U does not Granger cause LN_PO & 18 & 2,30666 & 0,1389 \\
LN_PO does not Granger cause LN_U & 18 & 0,4737 & 0,633 \\
LN_SMEs does not Granger cause LN_PO & 18 & 2,07991 & 0,0246 \\
LN_PO does not Granger cause LN_SMEs & 18 & 0,91037 & 0,4266 \\
\hline
\end{tabular}

(Source: Processed Data) 
urbanization has an important role in reducing poverty, especially in rural areas in developing countries. The results show a tendency that occurs, especially for rural communities which conduct urbanization due to economic factors and the desire of the people to meet their needs for better life without any skill and qualified level of education. Hence, it makes them apparently unable to compete until they become unemployed and impact the increase in poverty. The results also prove that the process of urbanization occurs as a result of differences in class in the economy, social, political, demographic, geographic, environmental, and so on.

The results have implications for the government to continue to commit to development in almost all rural sectors, such as industry and services. Besides that, the government needs to organize agrarian reform, empower rural communities and build rural infrastructure that will facilitate the economic processes in villages. The existence of the village-owned enterprises (BUMDes) program from the government for village autonomy must continue to be guarded so that there is no deviation in the use of budget for the development of the people's economy.

Fifth, there is a one-way causality between the role of SMEs towards poverty. It indicates that in the short term, the variation in the movement of the role of SMEs will drive poverty change in Indonesia.
The finding supports the studies conducted by Zafar et al. (2018), Yalo and Nafiu (2016), and Edom et al. (2015). They suggested that SMEs had a causal impact on poverty reduction. These findings suggest the important roles of SMEs in reducing poverty in Indonesia since SMEs serve as a provider of employment and a means of equitable distribution of people's welfare.

Next, the short-term VECM estimation analysis in Table 7 shows all coefficients of the CointEq1. The cointegration equation is significant. It indicated an adjustment mechanism from the short to long term towards the optimal target of economic growth.

Table 7 shows the number of SMEs at lag- 1 . It has a positive and significant effect on economic growth with a statistical t-value of 1,853592 . It is greater than t-table at the real level of 5\% $(1,67203)$ and $10 \%(-1,29658)$. The value of the coefficient variable of the number of SMEs is 1,612800. It means if there is an increase of $1 \%$ in the number of SMEs in one previous year, it will increase economic growth by $1,612800 \%$ in the current year. The coefficient of determination (R-squared) is 0,385361 , meaning that the effect of the number of SMEs and workers in SMEs on economic growth is $38,5361 \%$. Meanwhile, the remaining $(61,4639 \%)$ is determined by other factors.

Table 7 Estimation Results of the VECM Model

\begin{tabular}{lcccc}
\hline Error Correction & D(LN_GDP) & D(LN_PO) & D(LN_SMES) & D(LN_U) \\
\hline CointEq1 & 0,805519 & 0,046537 & 0,019404 & $1,45 \mathrm{E}-05$ \\
& $(0,01546)$ & $(0,03491)$ & $(0,00888)$ & $(0,00359)$ \\
& {$[1,20764]$} & {$[1,33318]$} & {$[2,18542]$} & {$[0,00404]$} \\
D(LN_GDP(-1)) & 0,155798 & 0,016192 & 0,011553 & 0,002811 \\
& $(0,15062)$ & $(0,03399)$ & $(0,00865)$ & $(0,00350)$ \\
D(LN_PO(-1)) & {$[1,03435]$} & {$[0,47635]$} & {$[1,33621]$} & {$[0,80329]$} \\
& 0,949316 & 0,030909 & 0,050381 & 0,004373 \\
& $(1,38418)$ & $(0,31237)$ & $(0,07945)$ & $(0,03215)$ \\
D(LN_SMES( -1)) & {$[0,68583]$} & {$[0,09895]$} & {$[0,63410]$} & {$[0,13602]$} \\
& 1,612800 & 0,581122 & 0,000960 & 0,063915 \\
& $(0,038499)$ & $(0,94443)$ & $(0,24022)$ & $(0,09721)$ \\
D(LN_U(-1)) & {$[1,853592]$} & {$[0,61531]$} & {$[0,00400]$} & {$[0,65749]$} \\
& $-2,431488$ & $-1,049081$ & 0,211658 & $-0,497148$ \\
& $(11,4850)$ & $(2,59184)$ & $(0,65924)$ & $(0,26678)$ \\
C & {$[-0,21171]$} & {$[-0,40476]$} & {$[0,32106]$} & {$[-1,86350]$} \\
& 0,512310 & $-0,035190$ & 0,024172 & 0,021191 \\
& $(0,19862)$ & $(0,04482)$ & $(0,01140)$ & $(0,00461)$ \\
& {$[2,57929]$} & {$[-0,78508]$} & {$[2,12020]$} & {$[4,59303]$} \\
\hline R-squared & 0,761353 & 0,175133 & 0,321901 & 0,322591 \\
Adj. R-squared & 0,661917 & 0,168561 & 0,039360 & 0,040337 \\
\hline
\end{tabular}


It can be explained that the role of SMEs takes time to influence poverty in the following year. It takes a year to determine the impact of the increase in the role of SMEs on poverty at a later stage. The results indicate that in Indonesia, the problem of poverty is not only about the inability to meet basic consumption needs and improve the conditions, but also the lack of employment opportunities to reach social and moral aspects, such as low levels of education, lack of health insurance, limited access to knowledge, the low quality of education, and so on. Efforts to reduce poverty must continue to be done, one of which is by involving the SMEs. There is a significant relationship between the role of SMEs and poverty alleviation (Kowo et al., 2019). It is also revealed that the severity of poverty due to economic and social difficulties and lack of employment opportunities can be reduced by promoting the SME sector and bilateral trade between neighboring countries (Manzoor et al., 2019).

Finally, the results are expected to be essential information for policymakers, not only in Indonesia but also in other countries, for two main reasons. First, the existence of a large number and role of SMEs open up employment opportunities that can potentially be a wheel of economic growth. It has an impact on reducing poverty levels. Second, urbanization will cause new problems in cities if it is not accompanied by an increase in employment and labor quality. The government, in this case, can seek economic equality in villages through optimization of economic development and encourage the reclassification of rural villages into urban villages.

\section{CONCLUSIONS}

From the Granger causality test results, it can be concluded that there is a one-way causality between poverty on economic growth, urbanization and economic growth, the role of SMEs and economic growth, and the role of SMEs on poverty. However, conversely, there is no two-way causality between urbanization and poverty and SMEs and urbanization. Then, the results of the VAR analysis show that the role of SMEs has a positive effect on poverty in the first year. It means that it takes a year to determine the impact of the increase in SMEs on poverty at a later stage. The research has several implications for government, namely: (i) compiling work programs that touch the community directly and strengthen the development of local wisdom products; (ii) conducting more intense training; (iii) emphasizing on improving the quality and standards of local wisdom products; (iv) building rural infrastructure that can facilitate the economic processes in the village.

The limitation of the research is the selection of data range. For future research, it is recommended to use monthly data. Therefore, further research can test the data using the ECM model or the ARDL model to explain long-term and short-term information from the data. It can be seen whether the empirical model is consistent with economic theory.

\section{REFERENCES}

Arouri, M., Youssef, A. B., \& Nguyen, C. (2017). Does urbanization reduce rural poverty? Evidence from Vietnam. Economic Modelling, 60(January), 253270.

Badan Pusat Statistik. (2019). Statistik Indonesia 2019. Retrieved from https://www. bps.go.id/publication/2019/07/04/ da ac 1 ba 18 cae 1 e 90706 ee 58 a/statistikindonesia-2019.html

BTN Properti. (2017). Outlook ekonomi 2017 - Ekonomi Indonesia memasuki fase pemulihan. Retrieved from https://www.btnproperti.co.id/blog/outlookekonomi-2017-ekonomi-indonesia-memasuki-fasepemulihan-1145.html

Datt, G., Ravallion, M., \& Murgai, R. (2016). Growth, urbanization, and poverty reduction in India. The World Bank.

Dewi, S., Majid, M. S. A., Aliasuddin, A., \& Kassim, S. H. (2018). Dynamics of financial development, economic growth and poverty alleviation: The Indonesian experience. The South East European Journal of Economics and Business, 13(1), 17-30.

Edom, G. O., Inah, E. U., \& Emori, E. G. (2015). Small and Medium Enterprises financing and poverty reduction in Nigeria: An empirical analysis. Journal of Economics and Sustainable Development, 6(11), 91-100.

Garza-Rodriguez, J. (2018). Poverty and economic growth in Mexico. Social Sciences, 7(10), 1-9.

Hayyu, A. M. N. F. (2019). Mengelola urbanisasi untuk pertumbuhan ekonomi. Retrieved March $10^{\text {th }} 2020$ from https://news.detik.com/kolom/d-4504255/ mengelola-urbanisasi-untuk-pertumbuhan-ekonomi

Ivić, M. M. (2015). Economic growth and development. Journal of Process Management - New Technologies, 3(1), 55-62.

Khemili, H., \& Belloumi, M. (2018). Cointegration relationship between growth, inequality and poverty in Tunisia. International Journal of Applied Economics, Finance and Accounting, 2(1), 8-18.

Kowo, S., Adenuga, O., \& Sabitu, O. (2019). The role of SMEs development on poverty alleviation in Nigeria. Insights into Regional Development, 1(3), 214-226.

Laily, N., \& Kurniawan, R. Y. (2016). Analisis pengaruh perkembangan Usaha Kecil Menengah (UKM) terhadap pertumbuhan Produk Domestik Regional Bruto (PDRB). Jurnal Pendidikan Ekonomi (JUPE), 4(3), 1-4.

Manzoor, F., Wei, L., Nurunnabi, M., \& Abdul Subhan, Q. (2019). Role of SME in poverty alleviation in SAARC region via panel data analysis. Sustainability, 11(22), $1-14$.

Nindi, A. G., \& Odhiambo, N. M. (2015). Poverty and economic growth in Swaziland: An empirical investigation. Managing Global Transitions: International Research Journal, 13(1), 59-74.

Potts, D. (2016). Debates about A frican urbanisation, migration and economic growth: What can we learn 
from Zimbabwe and Zambia? The Geographical Journal, 182(3), 251-264.

Siani, J. (2020). International remittances, poverty and growth into WAEMU countries: Evidence from panel cointegration approach. Economics Bulletin, 40(2), 1446-1456.

Sekretariat Negara RI. (2008). Undang-Undang Republik Indonesia Nomor 20 Tahun 2008 Tentang Usaha Mikro, Kecil dan Menengah. Retrieved from https:// www.ojk.go.id/sustainable-finance/id/peraturan/ undang-undang/Documents/Undang-Undang\%20 Nomor\%2020\%20Tahun\%202008\%20Tentang\%20 Usaha \%20 Mikro, \%20 Kecil, \%20dan \%20 Menengah.pdf

Tambunan, T. (2019). Recent evidence of the development of Micro, Small and Medium Enterprises in Indonesia. Journal of Global Entrepreneurship Research, 9(1), $1-15$.
Wilonoyudho, S., Rijanta, R., Keban, Y. T., \& Setiawan, B. (2017). Urbanization and regional imbalances in Indonesia. The Indonesian Journal of Geography, 49(2), 125-132.

Yalo, M. I., \& Nafiu, A. T. (2016). Factor analysis of Small and Medium Enterprises' challenges and its implications on poverty and unemployment in Dekina. Asian Research Journal of Arts \& Social Sciences, 1(2), 1-12.

Yanah, Y. (2019). The influence of small micro industries on economic growth. JEJAK: Jurnal Ekonomi dan Kebijakan, 12(2), 318-326.

Zafar, M., Waqas, M., \& Nawaz, M. (2018). Impact of Small and Medium Scale Enterprises on poverty reduction in developing country: A case of Pakistan. Pakistan Business Review, 20(3), 703-713 